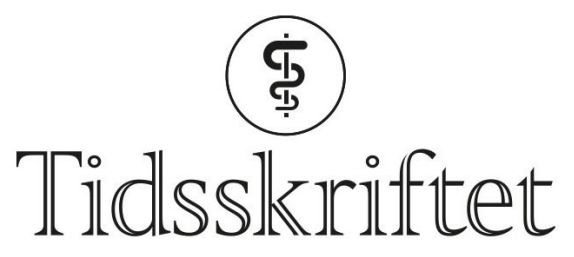

DEN NORSKE LEGEFORENING

\title{
- Verden må få vite hva som skjer
}

INTERVJU

IRENE THORESEN RØNOLD

E-post: irene.thoresen.ronold@tidsskriftet.no

Hanne Heszlein-Lossius mener det er legenes plikt å si ifra. - Det nytter ikke bare å gå på jobb og dele ut medikamenter og behandle symptomer. Man må behandle hele årsaken, sier hun.

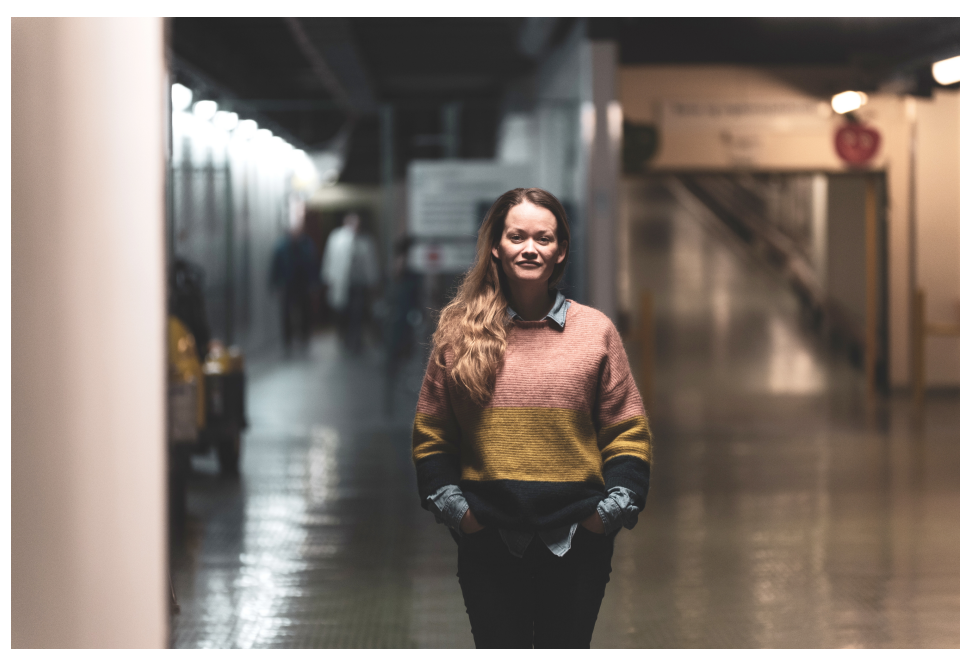

Alle foto: Magne Sandnes

De første nettene etter at Hanne Heszlein-Lossius var kommet hjem fra flyktningleiren Moria, hadde hun mareritt. Du vet den følelsen av å bråvåkne med et vagt ubehag i hele kroppen? Omtrent sånn var det.

- I tillegg fikk jeg en infeksjon da jeg kom hjem. Jeg har ikke noe behov for å forsøke å være tøff og late som jeg ikke ble påvirket. Jeg ble jo det.

Hun er journalisten som ble lege og aktivist. Siden flyktningstrømmen begynte å rulle inn over Europa i 2015 har 39-åringen fra Bergen vært i Hellas flere ganger. Hun har hjulpet i land overlessede gummibåter. Hun har møtt barn som er så kalde etter turen over havet at de i Norge ville ha blitt sendt til sykehus. Hun har behandlet brannskader, infeksjonssykdommer og forverring av kroniske sykdommer. Hun har møtt ungdommer med arr etter selvskading.

Det har aldri vært enkelt. Likevel - denne gangen var det tøffere enn tidligere.

- Det var hjerteskjærende, rett og slett. Når vi var i Hellas tidligere, så vi barn som lekte og lo. Folk hadde et håp om å komme seg videre. Det var ikke på samme måte denne gangen. 


\section{Fikk verden i hodet}

At helse og politikk henger sammen, er åpenbart for de fleste av Tidsskriftets lesere. Men det er som om det blir ekstra tydelig når man treffer Hanne Heszlein-Lossius.

I 2013 var hun med på å starte opp helsehjelp for papirløse flyktninger på hemmelig adresse i Bergen. Da hun var medisinstudent, overtalte hun Mads Gilbert til å la henne skrive studentoppgave i Gaza - et arbeid som la grunnlaget for doktorgraden om amputasjonsskader som hun er i ferd med å fullføre i disse dager. Og da hun jobbet som distriktslege i Berlevåg og ambulanseflyene sto på bakken, skrev hun et åpent brev til Bent Høie, delte det på Facebook og endte opp med å møte helseministeren til debatt på NRK i beste sendetid.

Selv mener trebarnsmoren at hun fikk sin politiske oppvåkning som 19-åring. Hennes daværende kjæreste jobbet på et høyfjellshotell i Sveits, og unge Hanne bestemte seg for å reise etter. Hun tok seg vaskejobb på samme hotell.

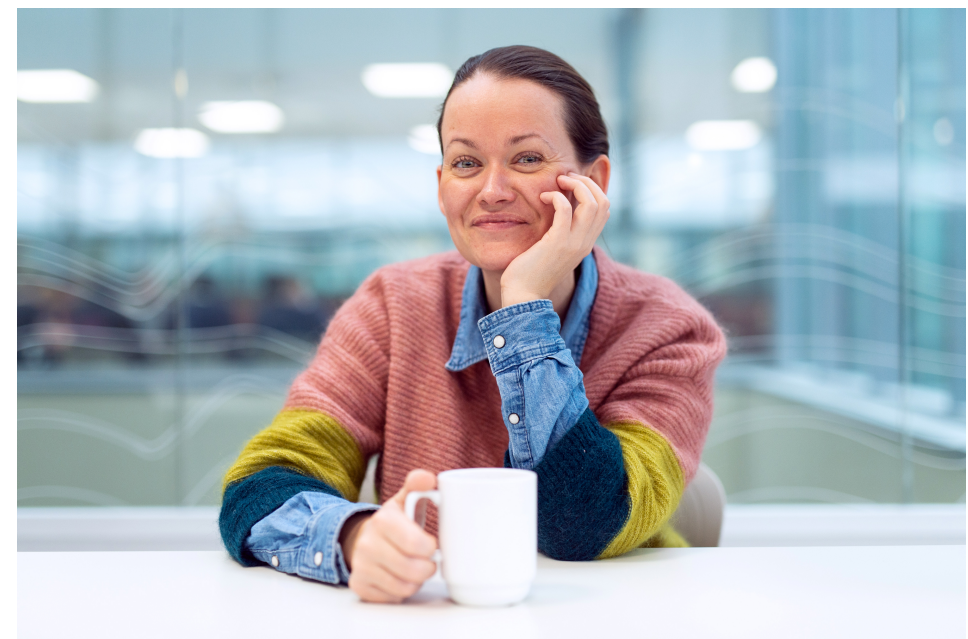

- Det var første gang jeg fikk verden litt i hodet. Jeg var fryktelig bortskjemt. Jeg trodde jeg skulle et år til Sveits for å jobbe litt, lære meg tysk og stå på snowboard. I stedet lærte jeg meg spansk, fordi det var språket alle fremmedarbeiderne snakket.

Hun ler, men opplevelsen var alvorlig nok.

- Det var første gang jeg kjente urettferdighet på kroppen. Jeg var rystet. Det var lange vakter, dårlig betalt, og vi som var ansatt på housekeeping hadde de dårligste rommene. Hvis det var noe som manglet, ble vi anklaget for å ha tatt ting. En gang jeg gikk til legen, fikk arbeidsgiveren min høre fra legen hva jeg hadde sagt og hvorfor jeg hadde vært der, sier hun.

- Jeg var heldig og kunne reise hjem til trygge Norge hvis jeg ville. Kvinnene jeg jobbet sammen med, hadde ikke det valget. De var der for å forsørge barna sine.

\section{Enorm styrke}

Når vi møter Heszlein-Lossius er det om lag tre uker siden hun kom hjem fra flyktningleiren Moria på den greske øya Lesvos. Der jobbet hun frivillig sammen med artist og sykepleier Marthe Valle.

Klinikken de jobbet ved besto av to konteinere. Heszlein-Lossius anslår at hun, sammen med fire andre leger, tok imot om lag 150 pasienter om dagen. Pasientene måtte vente utendørs, noen dager i minusgrader, under et tak bestående av en presenning som falt sammen en dag det kom ekstra mye regn.

Jeg trodde jeg skulle et år til Sveits for å jobbe litt, lære meg tysk og stå på snowboard. I stedet lærte jeg meg spansk, fordi det var språket alle fremmedarbeiderne snakket

- Det var tøft og tungt. Samtidig ser man utrolig mye styrke blant menneskene man treffer. 
Det er enormt krevende å komme seg gjennom den flukten som disse menneskene har vært på. Vi burde vært mer humane og rakt ut en hånd.

Leiren hun besøkte blir av flere beskrevet som helvete på jord. Ifølge FNs høykommissær for flyktninger lever det over 7 ooo flyktninger i leiren, som er dimensjonert for litt over 2 ooo. Den var ment å være en kortsiktig løsning. Men som et resultat av flyktningavtalen mellom EU og Tyrkia, som kom i stand i mars 2016, er tusenvis av flyktninger i praksis fanget på den greske øya.

- Folk bor i telt uten strøm og varmt vann mens det er minusgrader. Det sier seg selv at det ikke funker. Jeg mener alle bør si fra at dette ikke er greit. Hvem har bestemt at det skal være greit?

Hun er oppgitt i stemmen.

- Mange vil si «ja, ja, det er langt unna, det er ikke mitt ansvar» og nærmest skjerme seg litt fra det. Men det er faktisk sånn at det sitter tusenvis av mennesker i helt uverdige forhold $\mathrm{i}$ teltleirer i Europa. Vi hadde ikke trengt å ha flyktningleirer i Europa. Det er mer enn nok plass og rikdom til å gi mennesker på flukt verdige forhold og tak over hodet.

\section{Et ærlig yrke}

På mange måter var det alltid medisin som var drømmen. Men mangel på realfag og dårlige mattekarakterer gjorde at unge Hanne i stedet valgte å dra til Australia for å studere journalistikk. På spørsmål om hvorfor hun, etter å ha reist hjem igjen og fått seg jobb i Bergens Tidende, valgte å bytte til medisin, svarer hun med glimt i øyet at hun «måtte få seg et ærlig yrke».

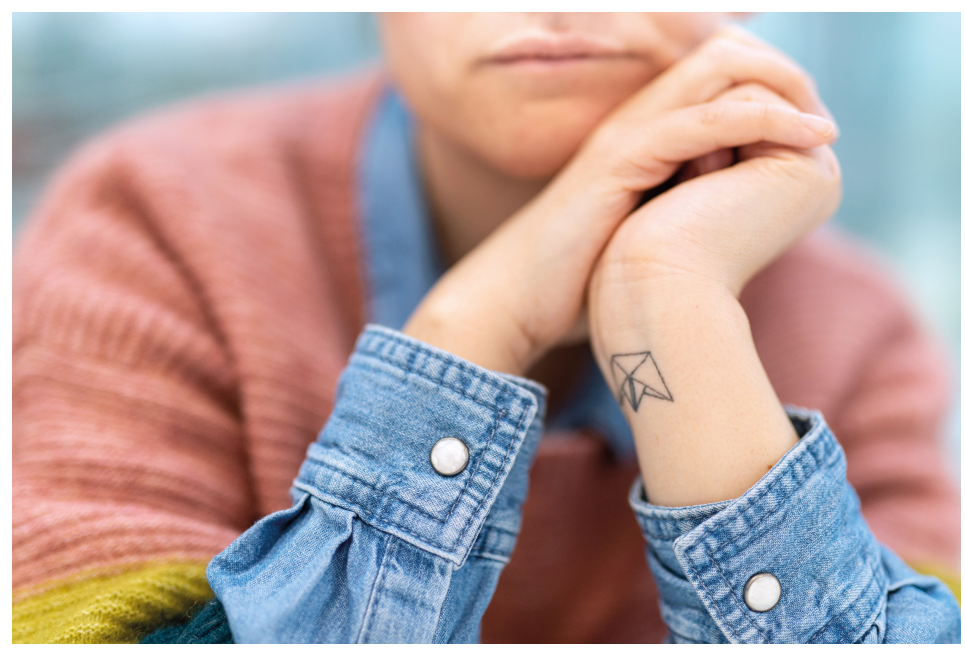

- Jeg har alltid hatt lyst til å jobbe med mennesker. Det gjør man som journalist også. Men jeg følte at det gikk veldig lang tid mellom hver gang jeg fikk skrive om noe jeg virkelig brant for.

Hun husker godt 27. desember 2008, da den nesten tre uker lange Gaza-krigen mellom Israel og Hamas startet med en rekke luftangrep på Gazastripen. Ettersom ingen journalister fikk rapportere derfra, var de eneste øyenvitnene til angrepene de norske legene Mads Gilbert og Erik Fosse.

- Jeg husker jeg tenkte at arbeidet de gjorde i Gaza den vinteren og her hjemme i etterkant, var enormt viktig. Jeg ønsket å bidra, hvis jeg kunne.

Da hun fikk sitt tredje barn, bestemte hun seg: Det var lege hun skulle bli. Mens ektemannen Morten var hjemme i pappapermisjon, brukte Hanne Heszlein-Lossius tiden på å ta opp matte, fysikk og kjemi.

- Det var ganske heftig. Men det handlet mye om motivasjon og arbeidsvaner. Det hadde jeg ikke hadde hatt så mye av tidligere, ler hun. 


\section{Hjemland nummer to}

Noen år ut i medisinstudiet kom tiden for å skrive studentoppgave.

- Jeg har en pappa som var en del i Palestina da jeg var liten, så jeg hadde hørt den palestinske historien. I tillegg har jeg en mann som er veldig engasjert i solidaritetsarbeid, så vi hadde snakket mye om den brutale uretten det palestinske folket opplever. Under angrepene i 2008 og 2009 var vi helt rystet. Når du virkelig setter deg inn i hva som har skjedd, er det vanskelig å forstå at dette får lov til å fortsette igjen og igjen. Da vi skulle skrive studentoppgave på studiet, hadde jeg lyst til å gjøre forskningsarbeidet mitt i Gaza.

\section{Hanne Heszlein-Lossius}

Født 1980 i Bergen

Gift, tre barn

Bachelor journalistikk Queensland, University of Technology (QUT) 2004

Styremedlem i Helsesenter for papirløse i Bergen 2013-15

Cand.med. Universitetet i Bergen 2015

Medisinsk turnustjeneste Haraldsplass Diakonale Sykehus 2015-16

Ph.d.-student Universitetet i Tromsø 2017-19

Distriktslege Berlevåg Finnmark 2017-18

LIS-lege anestesi Voss sjukehus 2018-

Mads Gilbert pleier egentlig å si nei til å ta med seg studenter ut. Men på en eller annen måte klarte Hanne Heszlein-Lossius å overtale ham. Nå står han som hennes veileder på doktorgraden.

Egentlig søkte hun forskerlinjen i Bergen, kan hun fortelle, men kom ikke inn. I stedet ble det doktorgrad ved Universitetet i Tromsø. Det har også gått fint: I vinter ble en av artiklene i doktorgradsarbeidet publisert i The Lancet Planetary Health. I artikkelen viste hun at de mest alvorlige skadene blant krigsoverlevere med amputasjoner var forårsaket av droner. Droner er et våpen som øker i bruk, og noen mener droner minimerer såkalt kollateral skade - altså uintendert skade på sivile.

- Det er en form for krigføring hvor man fjerner risikoen for eget militært personell ved å bruke fjernstyrte våpenbærende fly. Men det viser seg å være det som gir mest sivil skade.

Men det er faktisk sånn at det sitter tusenvis av mennesker i helt uverdige forhold i teltleirer i Europa

Hun er ordknapp om doktorgraden, som hun håper å kunne levere i løpet av sommeren. Når man spør om Gaza, derimot, har hun mer å fortelle. Hun beskriver Palestina som sitt andre hjemland.

- Gaza er alt. Det er helt forferdelig, fordi det er så stor menneskeskapt lidelse. Okkupasjonen og beleiringen har ført til stor fattigdom, mangel på strøm og rent drikkevann. Men som jeg fikk høre fra en god venn før jeg besøkte Gaza første gang i 2014: Første gang du drar dit, blir folk veldig glad for at du kommer. Når du har dratt dit andre gang, har du fått skikkelig gode venner. Og når du kommer tredje, fjerde, femte gang, har du fått en ny familie.

Samtidig legger hun ikke skjul på at arbeidet med doktorgraden har vært krevende.

- Det er klart det har vært en rekke hindre på veien. Men det gjør det enda viktigere å drive frem forskning fra steder som Gaza. Verden må få vite hva som skjer.

\section{Knuste kjøkkeninnredningen}

Da er det kanskje nyttig å være det venner vil karakterisere som ekstremt bestemt. Hanne 
Heszlein-Lossius fullfører det hun begynner på, og hun pleier å få det som hun vil. En yndet historie blant venner handler om hvordan Hanne som tenåring haiket med fly hjem fra Spania, etter at hun forsov seg til sin egen flyvning.

- Jeg er kjempesta. Jeg gir meg aldri. Det er kanskje noe jeg burde lært av, at jeg kunne latt enkelte ting passere.

- Er det sant at du har ødelagt en kjøkkeninnredning?

- Uff, ja. Men da var jeg gravid, på overtid. Da får man et sånt redeinstinkt, begynner hun.

- Poenget var: Vi hadde et flatpakket kjøkken i kjelleren, som Morten hadde lovet meg at han skulle sette opp før Sofia ble født. Det gjorde han ikke. Jeg hadde forsøkt å overtale ham, og han sa nei. Hun ler litt.

- Jeg kom ikke så veldig langt. Jeg tror jeg slo ned to skap eller noe sånt. Så kom han og hjalp til. Vi hadde et nytt kjøkken på plass før Sofia ble født.

\section{Drømmen om Berlevåg}

Nå er hun i spesialisering som anestesilege ved Voss sjukehus. Etter turnus i Bergen jobbet hun som lege i Berlevåg i Finnmark for å finansiere doktorgraden, og forelsket seg umiddelbart.

- Finnmark var helt fantastisk. Folk var så kule, jordnære og avslappet. Ting går stort sett bra. Det er 30 mil til nærmeste sykehus, så det hendte jeg fikk litt høy puls. Da fikk jeg høre «No må du slappe av». Berlevåginger vet hvor de bor, de er veldig modige og lite pysete.

Nå dør mennesker fordi vi har stengt grensene våre. Det er folk nødt til å forstå

Sommeren 2018 var imidlertid pulsen høy hos de fleste i Berlevåg. Etter at selskapet Lufttransport tapte anbudet på luftambulansetjenesten fra 1. juli 2019, ble flere av ambulanseflyene stående på bakken.

- Det var ganske drøyt. Jeg tenkte at dette sikkert blir fikset. Dette er jo en krise, en unntakstilstand, som er oppstått nå og som selvfølgelig er i orden i morgen. Det skjedde jo ikke, sier Heszlein-Lossius, og utdyper:

- Vi opplevde det som at beredskapen og sikkerheten til menneskene som bor der, ikke ble tatt på alvor. Det var faktisk noen døgn der alle fly stod på bakken. Vi gikk bare og ventet på at noe skulle gå galt. Å sette ambulanseflyene, akuttberedskapen i nord, ut på anbud er så hinsides at det aldri burde være lov.

- Ligger det for deg å si ifra?

- Ja, det gjør det. Det er man pliktig til som helsepersonell. Det nytter ikke bare å gå på jobb og gi ut medisiner. Man må behandle hele årsaken. I Berlevåg, som alle andre steder i Norge, har du et samfunnsansvar i kraft av å være legen til menneskene som bor der. Når akuttberedskapen ikke fungerer, må legene selvsagt si ifra.

\section{Tenker på egne barn}

Fire dager etter intervjuet med Tidsskriftet er det nettopp det hun skal gjøre. På Deichmanske bibliotek i Oslo skal hun møte partifeller i Rødt, i rollen som øyenvitne til det som skjer i flyktningleirene i Hellas. Hun skal fortelle om barn på tre år med alvorlige brannskader og om moren hun traff, som kom inn med kullosforgiftning etter å ha tent bål inne i en lukket konteiner. Hun har fortalt om henne til Tidsskriftet også:

- Kull ble brent uten nok tilgang på oksygen og kullos dannet seg inne i teltet. Denne kullosen hadde mammaen pustet inn. Det sier litt om hvordan forholdene var der. Hun fikk oksygenbehandling og var til observasjon på klinikken ganske lenge. Før hun gikk, sa jeg til henne at hun ikke måtte gjøre dette, at det var flaks at hun overlevde. Hun svarte: «Hva skal jeg gjøre, da? Jeg har jo tre barn. De fryser ihjel hvis jeg ikke kan varme teltet om natten». 
Slik jeg forsto henne, kom hun sikkert til å gjøre det igjen. Jeg ville gjort det samme selv. Hun hadde ikke noe valg.

- Hva tenker du da?

- Jeg tenker på mine egne barn. For meg er de de viktigste i verden. Men objektivt sett er de jo ikke det. Hennes barn er like viktige som mine barn. Nå dør mennesker fordi vi har stengt grensene våre. Det er folk nødt til å forstå.

Publisert: 20. juni 2019. Tidsskr Nor Legeforen. DOI: 10.4045/tidsskr.19.0354

(C) Tidsskrift for Den norske legeforening 2020. Lastet ned fra tidsskriftet.no 